\title{
Synthesis and Adsorption Properties of Multiwalled Carbon Nanotubes
}

\author{
Iryna Ivanenko and Tetiana Dontsova
}

\author{
National Technical University of Ukraine \\ 'Igor Sikorsky Kyiv Polytechnic Institute', \\ 37 Peremohy Ave., Bldg. 4, \\ UA-03056 Kyiv, Ukraine
}

Multiwalled carbon nanotubes (MWCNTs) were synthesized by carbon vapour deposition method onto the $\mathrm{Mo}, \mathrm{Fe} / \mathrm{MgO}$ catalyst, which was prepared with a precipitation method. The synthesis was carried out at four different temperatures: $600,700,800$, and $900^{\circ} \mathrm{C}$. It was found that the yield of carbon nanotubes increases in proportion to the increase of the synthesis temperature. For purification from catalyst residues and amorphous impurities, as-grown carbon nanotubes were treated with nitric acid (1:1) at boiling for 1 hour with subsequent washing with distilled water. Abundance of catalyst residues after such a treatment decreased from 35$70 \%$ to $2-6 \%$ that was established with complex thermal analysis. Highresolution transmission electron microscopy indicated that the length and diameter of the obtained multiwalled nanotubes vary depending on the temperature of their synthesis. It was concluded, as the higher temperature of synthesis is, the greater the length and diameter of produced carbon nanotubes are in these experimental conditions. The porous structure of both series of synthesized samples (initial as-grown and washed ones) was studied by the method of low-temperature adsorption-desorption of nitrogen. The obtained isotherms of nitrogen adsorption-desorption indicated that the synthesized samples demonstrate similar adsorption properties. The isotherms of all carbon nanotubes belong to the III type according to Brunauer classification, except the first washed sample, which demonstrated the isotherm of the II type. The pore diameter distributions, which were obtained by mathematical processing the adsorption isotherm with DFT method, discovered that the samples are characterized by the almost complete absence of micro- and mesopores, while macropores exist in a wide range of diameters from 5 to $30 \mathrm{~nm}$. The adsorption properties of the obtained MWCNTs were determined through adsorption of two dye types: cationic methylene blue and anionic Congo red from model aqueous solutions. The initial unwashed nanotubes illustrated the high affinity towards the anionic type dye and the almost complete absence of affinity 
to the cationic dye; moreover, their adsorption capacity does not depend on the temperature, at which they were obtained. The washed carbon nanotubes exhibit the opposite behaviour; they do not adsorb anionic dye at all, but they actively adsorb cationic dye, and their adsorption activity decreases with increasing temperature of their synthesis.

Багатостінні вуглецеві нанотрубки синтезували методою осадження парів вуглецю на каталізаторі $\mathrm{Mo}, \mathrm{Fe} / \mathrm{MgO}$, який одержували методою осадження. Синтезу проводили за чотирьох різних температур: 600, 700,800 i $900^{\circ} \mathrm{C}$. Встановлено, що вихід вуглецевих нанотрубок зростає пропорційно підвищенню температури синтези. Для очищення від залишків каталізатора й аморфних домішок вирощені вуглецеві нанотрубки обробляли нітратною кислотою $(1: 1)$ за кипіння протягом 1 години з подальшим відмиванням дистильованою водою. Вміст залишків каталізатора після такого оброблення зменшувався з $35-70 \%$ до $2-6 \%$, що було встановлено за допомогою комплексної термічної аналізи. Електронна мікроскопія з високою роздільчою здатністю показала, що довжина та діяметер одержаних багатостінних вуглецевих нанотрубок змінюються в залежності від температури їх синтези, а саме, чим вище температура синтези, тим більші довжина та діяметер синтезованих за даних експериментальних умов вуглецевих нанотрубок. Порувату структуру обох серій синтезованих зразків (як вихідних, так і відмитих) вивчали методою низькотемпературної адсорбції-десорбції азоту. Одержані ізотерми адсорбції-десорбції азоту вказували на те, що синтезовані зразки демонструють подібні адсорбційні властивості. Ізотерми всіх вуглецевих нанотрубок належать до III типу за Брунауеровою класифікацією, за винятком першого промитого зразка, який продемонстрував ізотерму II типу. Розподіл діяметрів пор, одержаний шляхом математичного оброблення ізотерми адсорбції методою DFT, виявив, що синтезовані зразки вуглецевих нанотрубок характеризуються майже повною відсутністю мікропор, однак вони володіють розвиненою мезопоруватістю 3 превалювальним діяметром пор від 25 до 30 нм. Адсорбційні властивості вуглецевих нанотрубок визначали шляхом адсорбціі двох типів барвників: катіонного метиленового синього й аніонного конго червоного з модельних водних розчинів. Вихідні невідмиті нанотрубки ілюстрували високу спорідненість до барвника аніонного типу та майже повну відсутність споріднености до катіонного барвника; більше того, їхя адсорбційна здатність не залежала від температури, за якої вони були синтезовані. Відмиті вуглецеві нанотрубки показали іншу тенденцію: вони взагалі не поглинали аніонний барвник, але активно адсорбували катіонний, а їхня адсорбційна активність зменшувалася зі збільшенням температури іх синтези.

Key words: multiwalled carbon nanotubes, synthesis, adsorbent, dye.

Ключові слова: багатостінні вуглецеві нанотрубки, синтеза, адсорбент, барвник.

(Received 28 April, 2020) 


\section{INTRODUCTION}

Multiwalled carbon nanotubes (MWCNTs) are becoming more common as effective sorbents, due to a number of distinctive features: high specific surface area [1], a developed system of cylindrical pores [2], selectivity to certain adsorptive types [3], chemical stability [4], and mechanical strength [5]. This fact, along with that carbon nanotubes have a higher capacity, can cause the replacement of active carbon by MWCNTs in various sorption processes from liquid and gaseous media [6,7] and as stationary phases in chromatography [8].

Carbon nanotubes are frame cylindrical nanostructures formed by folding a graphene grid into a seamless cylinder, in which the carbon atoms are arranged in hexagons [9]. Multilayered carbon nanotubes consist of a multitude of concentric cylinders held by Van der Waals forces [10].

The structural and adsorption properties of carbon nanotubes substantially depend on the method and conditions of synthesis [11]; therefore, the establishment of this dependence is an important task, which allows predicting the possibility of using the obtained sample in a particular area.

Various dyes of both anionic and cationic types are one of the most widespread pollutants of the aquatic environment. About 100000 different types of dyes are produced in the modern world [12-16]. The dye industries along with the textile industry are the main sources of this pollutant type. Such water-soluble dyes are highly toxic and resistant to removal. In water treatment processes, a number of ways are used to remove such pollutants that can be divided into biological, chemical and physical [17]. Biological methods include the use of microorganisms (bacteria, fungi, and algae) and characterized by low energy requirements and demand in toxic chemicals. Chemical methods include oxidizing (for instance, the Fenton process), photo- and electrochemical methods have a high demand for expensive and toxic reagents [18-19]. Among physical methods, adsorption, ion exchange, and membrane filtration can be distinguished.

Adsorption on porous sorbents is one of the most common and effective methods for removing dissolved dyes. For these purposes, active carbon is widely used in powder and granular form. However, as an alternative, MWCNTs can be used, the cost of which decreases every year.

For this reason, the purpose of the present work was the synthesis of multiwalled carbon nanotubes at different temperatures and the study of their adsorption properties toward anionic and cationic dyes Congo red and methylene blue. 


\section{EXPERIMENT}

\subsection{Preparation of the Multiwalled Carbon Nanotubes}

The carbon nanotubes were synthesized by carbon vapour deposition method (CVD) onto the $\mathrm{Mo}, \mathrm{Fe} / \mathrm{MgO}$ catalyst, which was prepared with a precipitation method. For this, the initial solutions $\left(\mathrm{NH}_{4}\right)_{6} \mathrm{Mo}_{7} \mathrm{O}_{24}$ and $\mathrm{Fe}\left(\mathrm{NO}_{3}\right)_{3}$ were mixed, the powder of $\mathrm{MgO}$ was added and stirred for 3 hours, then, the obtained suspension was heated up to $80^{\circ} \mathrm{C}$ and stayed at this temperature for overnight. The obtained catalytic mass was milled and calcined at $550^{\circ} \mathrm{C}$ for 2 hours in the air.

The CVD process was carried out in a horizontal quartz reactor in electric oven connected with gas mixing system at atmospheric pressure. About $100 \mathrm{mg}$ of fresh catalyst was placed on a ceramic boat and located at the middle of reactor. The reactor was heated to the required temperature $\left(600,700,800\right.$ and $\left.900^{\circ} \mathrm{C}\right)$ in a nitrogen flow $(150 \mathrm{~mL} / \mathrm{min})$ at heating rate of $10^{\circ} \mathrm{C} / \mathrm{min}$. When the required temperature reached, acetylene with the flow of $50 \mathrm{~mL} / \mathrm{min}$ was introduced. In this way, a mixture of these two gases was in the ratio of $3: 1$. This mixed gas was further introduced into the reactor for 1 hour. Then, the reactor was cooled down to the ambient temperature under nitrogen flow. The yield of carbonaceous deposit after reaction, $Y_{c}$, was calculated using the formula below according [20]: $Y_{c}=\left(W_{d e p}-W_{k a t}\right) / W_{k a t}$, where $W_{d e p}$-weight of carbon deposit, $W_{k a t}-$ weight of used catalyst.

For purification from catalyst residues and amorphous impurities, as-grown MWCNTs were treated with nitric acid (1:1) at boiling for 1 hour with subsequent washing with distilled water. Thus, two groups, as-grown and washed ones, with four samples in each, were obtained. The designations and characteristics of the obtained eight samples of MWCNTs are presented in Table 1.

TABLE 1. Samples designation.

\begin{tabular}{c|c|c}
\hline Designation & Synthesis temperature, ${ }^{\circ} \mathrm{C}$ & Washing \\
\hline 1.1 & 600 & initial unwashed \\
1.2 & 700 & initial unwashed \\
1.3 & 800 & initial unwashed \\
1.4 & 900 & initial unwashed \\
2.1 & 600 & washed \\
2.2 & 700 & washed \\
2.3 & 800 & washed \\
2.4 & 900 & washed \\
\hline
\end{tabular}




\subsection{Instrumental Tests}

High-resolution transmission electron microscopy (HTEM) was performed on a FEI Tecnai 12 TEM with accelerating voltage of $120 \mathrm{kV}$ at the accelerating voltage of $10 \mathrm{keV}$.

TG analysis was performed on a NETZSCH TG 209F1. Approximately $5 \mathrm{mg}$ of material was heated from 25 to $1000^{\circ} \mathrm{C}$ at the ramping rate of $10^{\circ} \mathrm{C} / \mathrm{min}$ under $\mathrm{O}_{2}$ and $\mathrm{N}_{2}$ mix gas (1:4).

Porous structure of synthesized samples was studied by the method of low-temperature adsorption-desorption of nitrogen on a Quatachrome Nova 1000 e apparatus. The distribution of pore radius is calculated by the method of Density Functional Theory (DFTmethod). By mathematical processing of nitrogen adsorptiondesorption isotherms were calculated: BET specific surface area $\left(S_{s p}\right.$, $\left.\mathrm{m}^{2} / \mathrm{g}\right)$, total pore volume for pores with radius less than $185 \mathrm{~nm}$ at $P / P_{o}=0.99\left(V_{\Sigma}, \mathrm{cm}^{3} / \mathrm{g}\right)$, micropores volume $\left(V_{\text {micro }}, \mathrm{cm}^{3} / \mathrm{g}\right)$, and average pores diameter $\left(d_{\text {pore }}, \mathrm{nm}\right)$.

\subsection{Adsorption Activity Studies}

The adsorption properties of the obtained MWCNTs were determined through adsorption of two dye types: cationic methylene blue (MB) and anionic Congo red (CR) from model aqueous solutions. The structural formulas of these dyes are shown in Fig. 1.

Typically, in adsorption tests, $50 \mathrm{mg}$ of carbon nanotubes was mixed with $10 \mathrm{~cm}^{3}$ of dyes solution (MB or CR) and ultrasonicated for 10 and $20 \mathrm{~min}$. After centrifugation during $30 \mathrm{~min}$, residual concentrations of dyes solution were determined by using spectrophotometer UV-1200 and the adsorption rate $(A, \%)$ was calculated according to the formula $A=\left(C_{\text {init }}-C_{\text {res }}\right) / C_{\text {init }}$, where $C_{\text {init }}$-initial concentration of dyes solution, $\mathrm{mg} / \mathrm{g}$, and $C_{r e s}$-residual concentration of dyes solution, $\mathrm{mg} / \mathrm{g}$.

\section{RESULTS AND DISCUSSION}

The yield of the obtained nanotubes depending on the synthesis temperature is displayed in Fig. 2 as a histogram. In this figure, it is seen that the yield of the resulting nanotubes increases in proportion to the increase of the synthesis temperature. It is obvious that the maximum yield of multiwalled carbon nanotubes is achieved at the highest investigated temperature of $900^{\circ} \mathrm{C}$.

The results of the thermal analysis of the obtained carbon nanotubes before and after purification are presented in Fig. 3. As can be seen in Fig. 3, $a$, the initial nonwashed nanotubes contain a large 


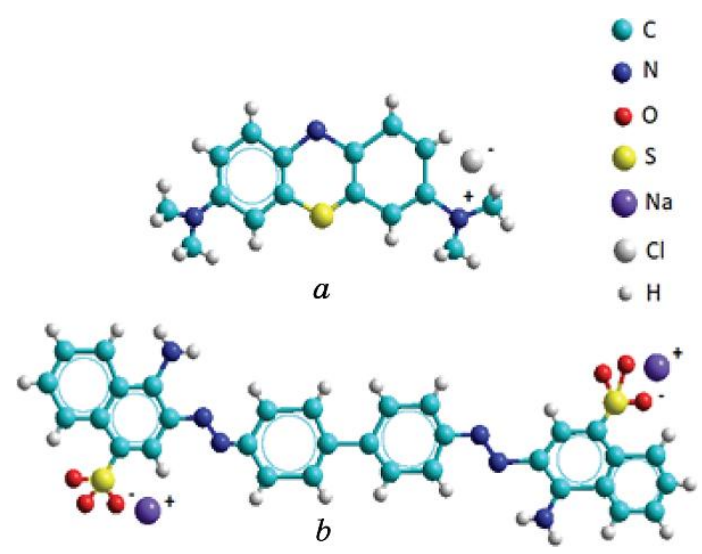

Fig. 1. The structural formulas of methylene blue $(a)$ and Congo red $(b)$.

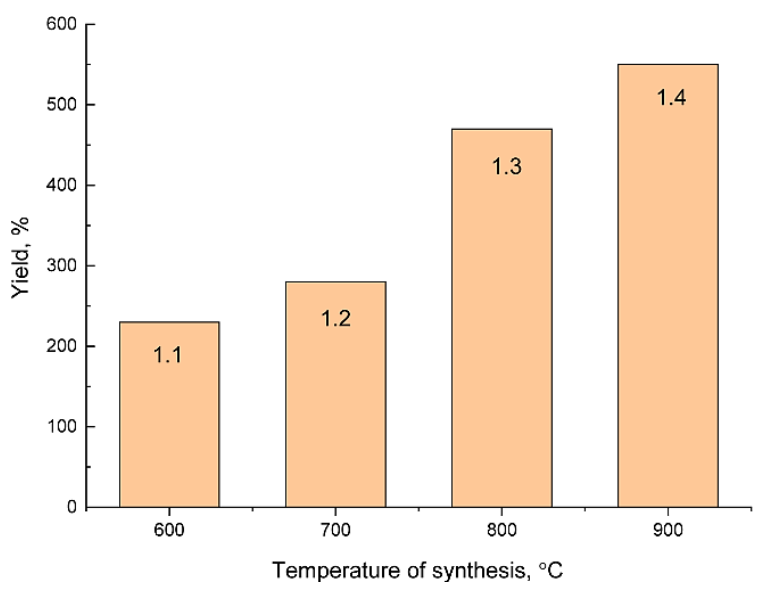

Fig. 2. Dependence of MWCNTs yield on the temperature of synthesis.

amount of the catalyst used in the synthesis. The largest amount of catalyst $(70 \%)$ contains in nanotubes synthesized at a temperature of $600^{\circ} \mathrm{C}$. Carbon nanotubes, which were obtained at a temperature of $900^{\circ} \mathrm{C}$, contain slightly less mineral impurities $(65 \%)$. The smallest amount of catalyst $(35 \%)$ is present in the carbon material synthesized at medium temperatures (of $700^{\circ} \mathrm{C}$ and $800^{\circ} \mathrm{C}$ ).

Thermograms of MWCNTs after boiling with nitric acid (1:1) and thorough washing with distilled water to a neutral $\mathrm{pH}$ are pictured in Fig. 3, $b$. As seen in Fig. 3, $b$, the most heat-resistant nanotubes are nanotubes obtained at average temperatures of $700^{\circ} \mathrm{C}$ and $800^{\circ} \mathrm{C}$. The content of mineral impurities within them after washing is almost the same, i.e., it is $\cong 4 \%$. The highest content of catalyst 

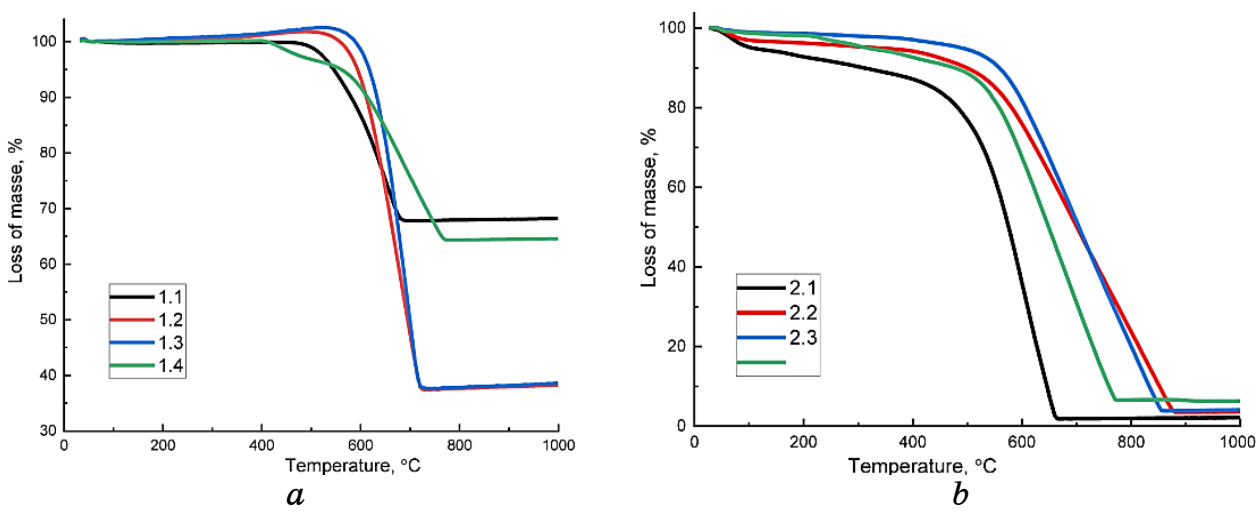

Fig. 3. Thermograms of initial (a) and washed (b) MWCNTs.

residues $\cong 6 \%$ is observed in nanotubes synthesized at the highest temperature. The nanotubes obtained at a lower temperature have the least heat resistance; however, the content of mineral impurities within them is the smallest, and it does not exceed $2 \%$.

The structure and morphology of the obtained nanotubes after washing were studied by the HRTEM method. The results of this study are shown in Fig. 4, which indicates that the length and diameter of the obtained multiwalled nanotubes vary depending on the temperature of their synthesis. As reflected in Fig. 4, $a, b$, the nanotubes obtained at $600^{\circ} \mathrm{C}$ have a length of $500 \mathrm{~nm}$ and a diameter of 7-10 nm. Figures 4,,$d$ illustrate tubes synthesized at $700^{\circ} \mathrm{C}$, which have a length of $700 \mathrm{~nm}$ and a diameter of 10-12 nm. The tubes obtained at $800^{\circ} \mathrm{C}$ show a length of $700 \mathrm{~nm}$ and a diameter of $12-15 \mathrm{~nm}$, as can be seen in Fig. 4, $e, f$. Nanotubes synthesized at the highest temperature $\left(900^{\circ} \mathrm{C}\right)$ acquire the largest diameter and length: a length of $1000 \mathrm{~nm}$ and a diameter of $15-20 \mathrm{~nm}$, as can be seen in Fig. $4, j, h$.

Thus, it can be concluded, as the higher temperature of synthesis is, the greater the length and diameter of produced carbon nanotubes are in these experimental conditions.

The structural-adsorption characteristics of the obtained nanotubes were investigated, using the method of low-temperature adsorption-desorption of nitrogen. The obtained isotherms of nitrogen adsorption-desorption are presented in Fig. 5. As can be seen, almost all the synthesized samples demonstrate similar adsorption properties. The isotherms of all carbon nanotubes belong to the III type (according to Brunauer classification) except the sample 2.1, which demonstrates the isotherm of the II type. In the case of the sample 2.1, the initial rapid increase in nitrogen adsorption, as well as the presence of a hysteresis loop in the high-pressure region, in- 

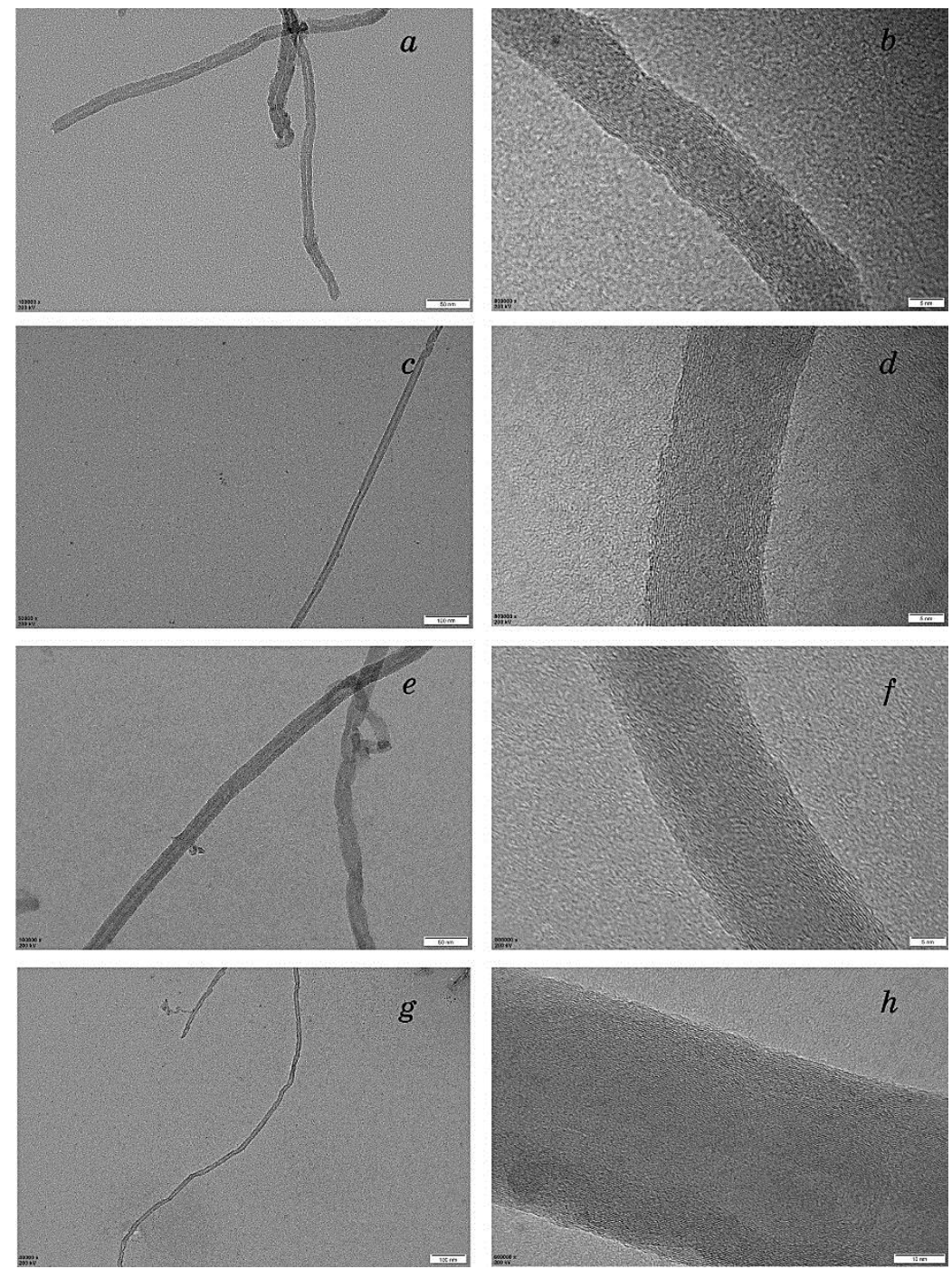

Fig. 4. HRTEM images of obtained MWCNTs after washing.

dicates the existence of a certain amount of micro- and mesopores, but this quantity is insignificant.

For the remaining samples, the general view of the adsorption isotherm, as well as the presence of a slight hysteresis loop, indicates that adsorption occurs mainly on the outer surface of the sample, while micro- and mesopores are practically absent.

The pore-diameter distribution graphs, which obtained by mathematical processing the adsorption isotherm (see Fig. 5) with DFT 

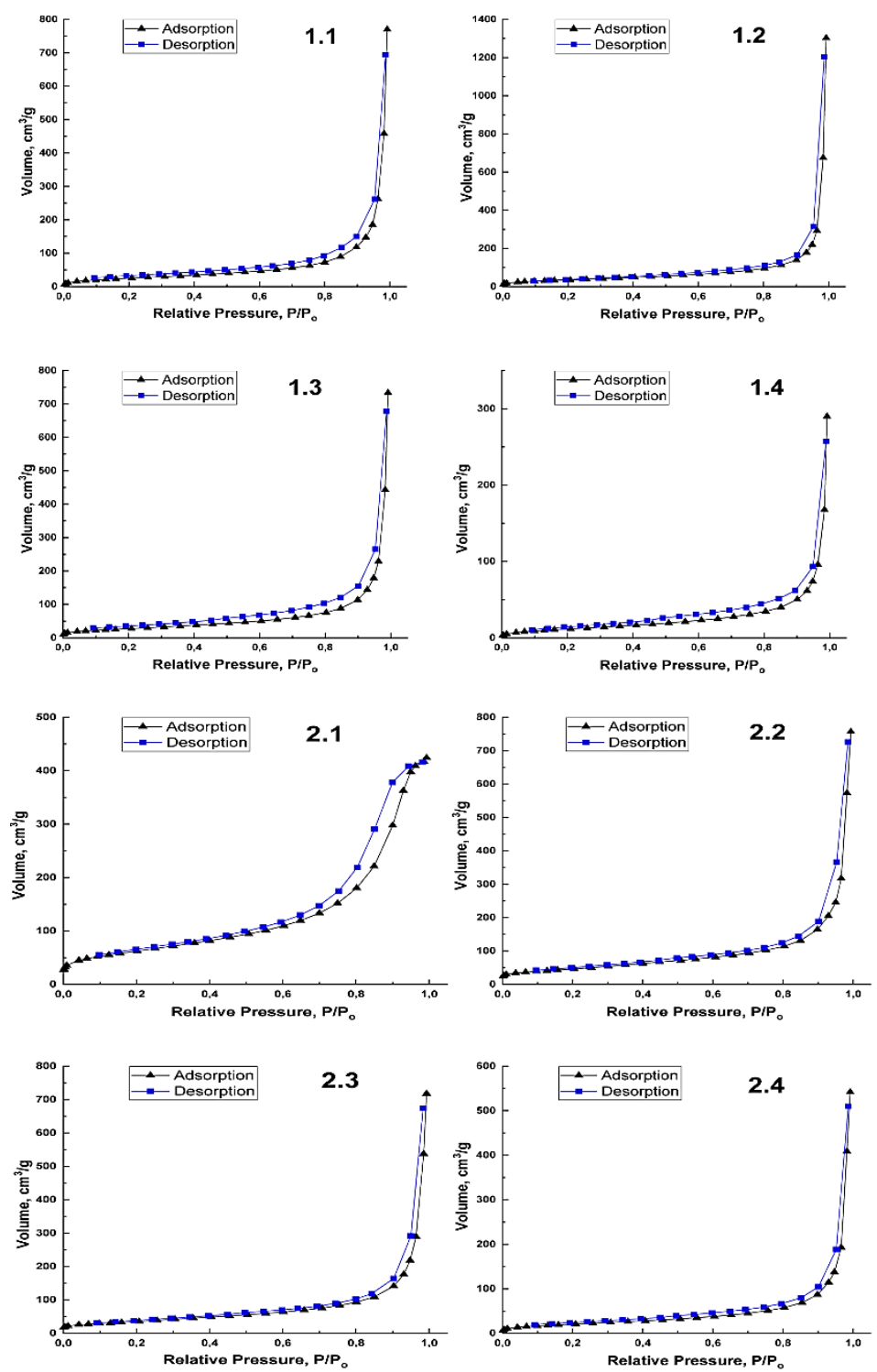

Fig. 5. Isotherms of low-temperature adsorption-desorption of nitrogen obtained onto initial unwashed $(1.1,1.2,1.3,1.4)$ and washed $(2.1,2.2$, $2.3,2.4$ ) carbon nanotubes.

method, are in Fig. 6. As may be inferred from the obtained graphs, the samples are characterized by the almost complete absence of micro- and mesopores, while macropores exist in a wide range of diameters from 5 to $30 \mathrm{~nm}$.

The BET specific surface area $\left(S_{\mathrm{sp}}, \mathrm{m}^{2} / \mathrm{g}\right)$, total porosity $\left(V_{\Sigma}\right.$, 

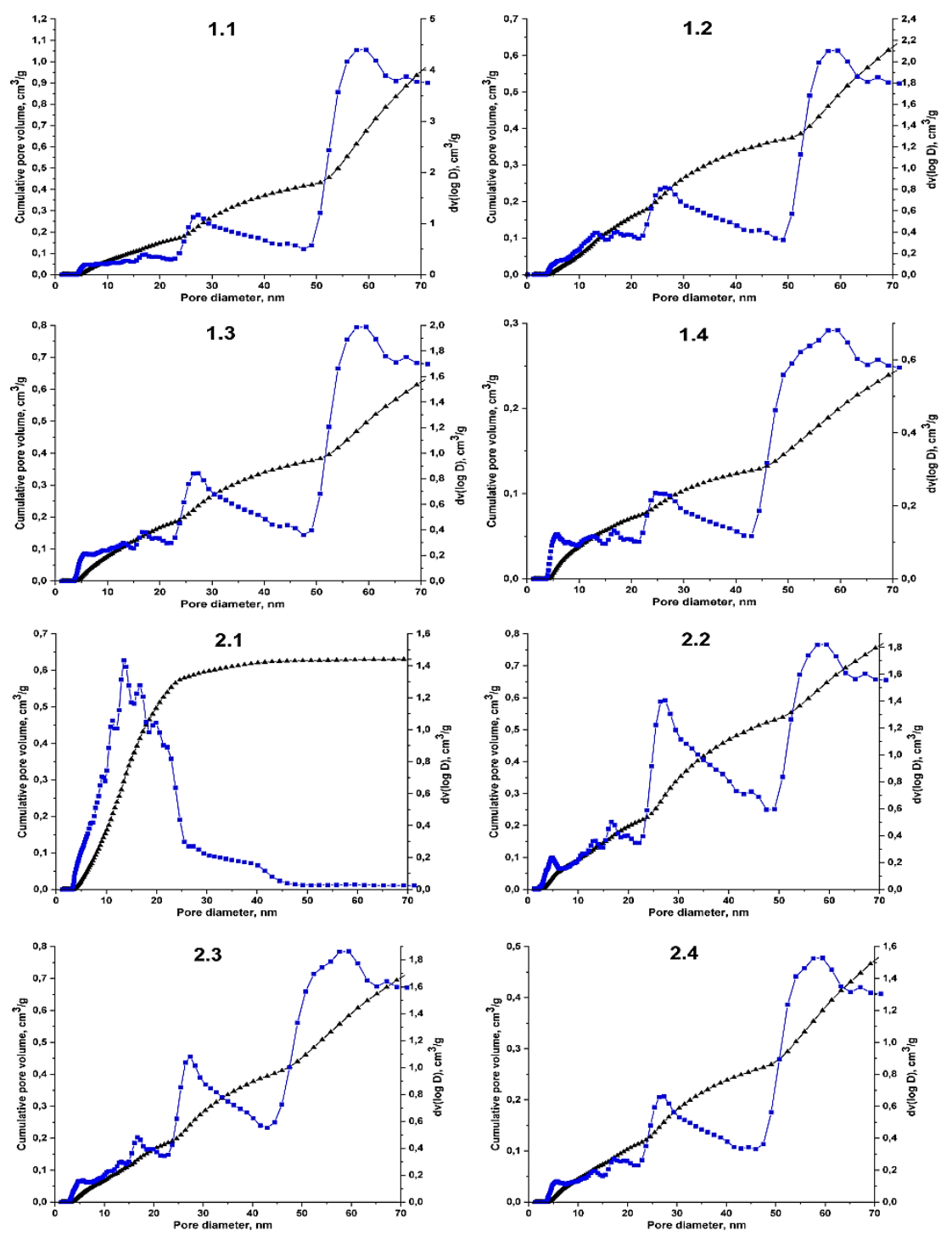

Fig. 6. Pores' diameters' distribution of initial unwashed $(1.1,1.2,1.3$, $1.4)$ and washed $(2.1,2.2,2.3,2.4)$ MWCNTs.

$\left.\mathrm{cm}^{3} / \mathrm{g}\right)$, micropores volume $\left(V_{\text {micro }}, \mathrm{cm}^{3} / \mathrm{g}\right)$, and average pores diameter $\left(d_{\text {pore }}, \mathrm{nm}\right)$ of all obtained MWCNTs are shown in Table 2.

As can be seen from the table, for both initial and washed nanotubes, $S_{s p}$ decreases in proportion to an increase in the temperature of their synthesis. Washed tubes synthesized at the lowest temperature have the highest specific surface area, as expected, based on their adsorption-desorption isotherms for nitrogen. The micropores' 
TABLE 2. The structural-adsorption characteristics of MWCNTs.

\begin{tabular}{c|cccccc}
\hline Treatment & Sample & $S_{s p}, \mathrm{~cm}^{3} / \mathrm{g}$ & $V_{\Sigma}, \mathrm{cm}^{3} / \mathrm{g}$ & $V_{\text {micro }}, \mathrm{cm}^{3} / \mathrm{g}$ & $d_{\text {pore }}, \mathrm{nm}$ \\
\hline \multirow{4}{*}{ Initial unwashed } & 1.1 & 130 & 2.0 & 0.04 & 0.6 \\
& 1.2 & 100 & 1.2 & 0.03 & 0.6 \\
& 1.3 & 105 & 1.1 & 0.03 & 0.4 \\
& 1.4 & 50 & 0.4 & 0.02 & 0.4 \\
\hline \multirow{5}{*}{ Washed } & 2.1 & 225 & 0.7 & 0.08 & 12 \\
& 2.2 & 170 & 1.1 & 0.06 & 0.3 \\
& 2.3 & 130 & 1.1 & 0.04 & 0.3 \\
& 2.4 & 80 & 0.8 & 0.02 & 0.4 \\
\hline
\end{tabular}

volume and average pores' diameter of both the initial and washed nanotubes also decrease in proportion to the increase in their synthesis temperature. For total porosity, a strict dependence on the production temperature is not observed.

Subsequent experiments had shown that the initial untreated nanotubes and nanotubes washed from the catalyst residues are very different in their adsorption behaviour in solutions. In addition, the temperature of synthesis of nanotubes greatly affects their adsorption capacity.

For example, in Fig. 7, $a$, which illustrates the adsorption of methyl blue by the initial unwashed nanotubes after 20 minutes of contact, it is seen that the degree of its adsorption does not exceed $7 \%$. Initial unwashed nanotubes adsorb Congo red dye much more actively. As reflected in Fig. 7, $b$, all samples of the initial nano-
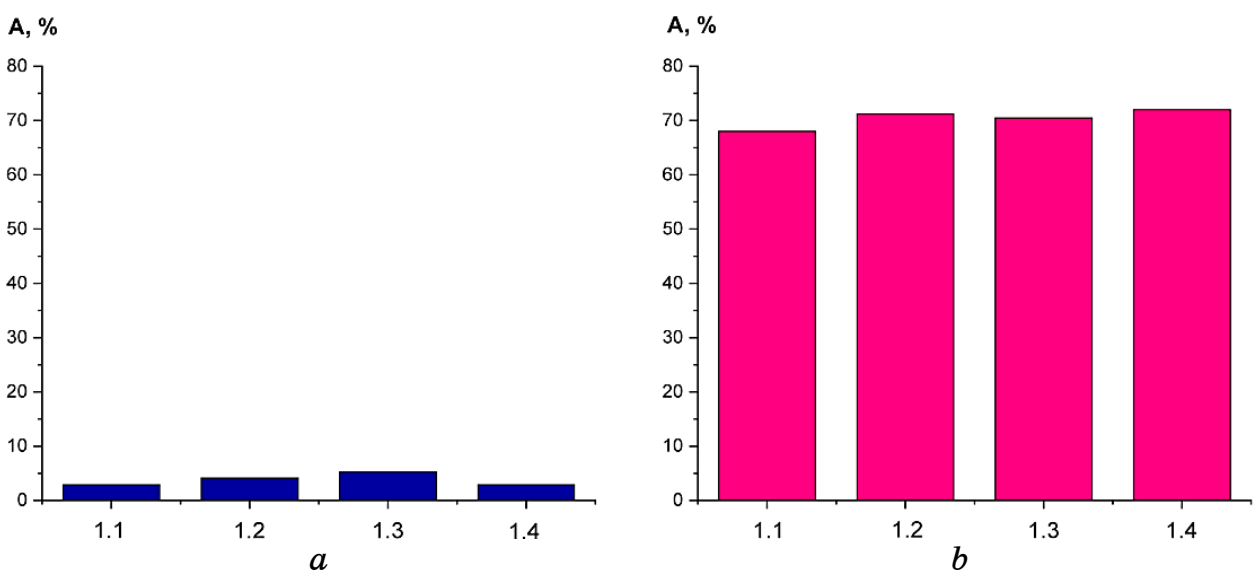

Fig. 7. Adsorption rate of $\mathrm{MB}(a)$ and $\mathrm{CR}(b)$ after $20 \mathrm{~min}$ by initial unwashed MWCNTs. 
tubes show approximately the same adsorption capacity towards the anionic type dye, which is $\cong 70 \%$. Such experimental data clearly illustrate the greater affinity of the initial unwashed nanotubes to the anionic dye and the almost complete absence of affinity for the cationic dye.

The results of a study of the adsorption properties of washed nanotubes are presented in Fig. 8. The washed nanotubes showed high adsorption activity towards methylene blue even after a 10minute contact, as shown in Fig. 8, $a$. Samples 2.1 and 2.2 after 10 minutes of adsorption reached an adsorption capacity of 72 and $45 \%$, respectively. After 20 minutes of adsorption equilibrium, higher values of adsorption capacity were achieved, as can be seen in Fig. 8, $b$. A tendency towards a decrease of adsorption activity with an increase of the temperature of nanotubes synthesis is also clearly visible, which is most likely associated with a proportional decrease of their surface area (see Table 2).

It is important to note that none of the washed nanotube samples showed any noticeable adsorption towards Congo red dye. This allows us to conclude that the clean surface of carbon nanotubes has a high affinity towards the cationic dye and that there is no affinity to the anionic dye, i.e., their behaviour is completely opposite to the behaviour of the initial unwashed nanotubes.

In our opinion, such a difference in the adsorption properties of carbon nanotubes can be explained as follows. The initial unwashed nanotubes contain from 30 to $70 \%$ of the non-combustible residue, that is a mixture of metals and their oxides (see Fig. 3,a), which act as active adsorption centres for anionic dyes. The nanotubes washed with nitric acid are practically free of metals and their ox-
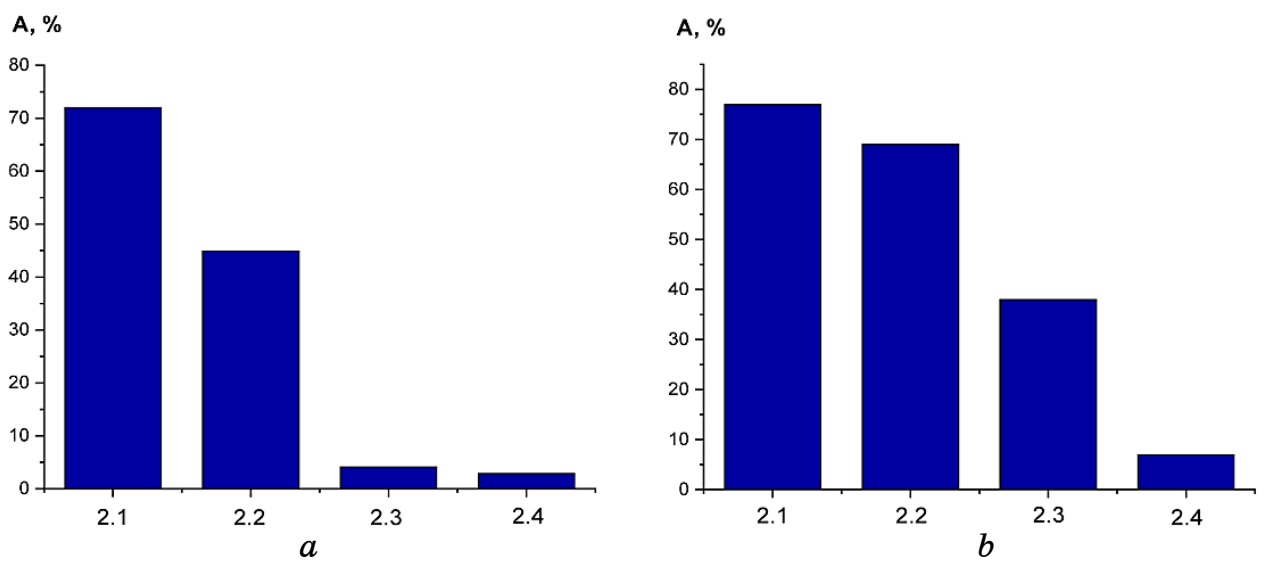

Fig. 8. Adsorption rate of MB by washed MWCNTs after 10 minutes (a) and 20 minutes $(b)$. 
ides, but their surface was coated with carboxylic, phenolic and other polar functional groups, during the boiling process with acid, which dissociate in solutions and act as adsorption centres for cationic dyes.

Such an explanation of the differences in the adsorption behaviour of the initial and washed nanotubes excludes the ion-exchange adsorption mechanism and confirms the physical nature of the adsorption of dyes. It proceeds due to dipole-dipole attraction between dye molecules (constant dipoles) and the surface of nanotubes containing dipoles in the form of catalyst residues and functional groups, i.e., mainly due to the orientation-dependent Van der Waals forces.

\section{CONCLUSIONS}

Multiwalled carbon nanotubes were synthesized by the SVD method at four different temperatures using a $\mathrm{Mo}, \mathrm{Fe} / \mathrm{MgO}$ catalyst. It was found that the carbon deposit yield increases in proportion to the increase of the synthesis temperature.

Boiling the obtained carbon deposit with nitric acid (1:1) for 1 hour provides purification from catalyst residues up to $94-98 \%$. Nanotubes obtained at a temperature of $900^{\circ} \mathrm{C}$ after washing contain the largest amount of catalyst. The surface area, the micropore volume, and the average diameter of the initial and washed obtained nanotubes are in direct proportion to their synthesis temperature.

The initial unwashed nanotubes illustrate the high affinity towards the anionic type dye and the almost complete absence of affinity to the cationic dye; moreover, their adsorption capacity does not depend on the temperature, at which they were obtained. The washed carbon nanotubes exhibit the opposite behaviour; they do not adsorb anionic dye at all, but they actively adsorb cationic dye, and their adsorption activity decreases with increasing temperature of their synthesis.

The differences in the adsorption properties of initial unwashed and washed nanotubes confirm the physical nature of the adsorption, which proceeds due to dipole-dipole attraction between dye molecules (constant dipoles) and the surface of carbon nanotubes.

\section{REFERENCES}

1. I. Hasanzadeh and M. J. Eskandari, Surf. Coat. Techn., 381: 125109 (2020); https://doi.org/10.1016/j.surfcoat.2019.125109

2. X. Li, W. Chen, and Ch. Zou, Pow. Techn., 361: 957 (2019); https://doi.org/10.1016/j.powtec.2019.10.106 
3. M. Matandabuzo and P. A. Ajibade, J. Molec. Liq., 296: 111778 (2019); https://doi.org/10.1016/j.molliq.2019.111778

4. J. Dou, D. Gan, Q. Huang, M. Liu, J. Chen, F. Deng, X. Zhu, Y. Wen, X. Zhang, and Y. Wei, Int. J. Biol. Macromol., 136: 476 (2019); DOI: $10.1016 /$ j.ijbiomac.2019.06.112

5. M. Kurkowska, S. Awietjan, R. Kozera, E. Jezierska, and A. Boczkowska, Chem. Phys. Lett., 702: 38 (2018); https://doi.org/10.1016/j.cplett.2018.04.056

6. O. A. Shabaan, H. S. Jahin, and G. G. Mohamed, Arab. J. Chem., 13, No. 3: 4797 (2020); https://doi.org/10.1016/j.arabjc.2020.01.010

7. P. M. Lutsyk, P. Shankar, A. G. Rozhin, and S. A. Kulinich, Surf. Interf., 17: 100363 (2019); https://doi.org/10.1016/j.surfin.2019.100363

8. Y. Zhang, Y. Dang, X. Lin, K. An, J. Li, and M. Zhang, J. Chrom. A, 460939 (2020); https://doi.org/10.1016/j.chroma.2020.460939

9. B. Verma and C. Balomajumder, Envir. Techn. Innov., 17: 100596 (2019); https://doi.org/10.1016/j.eti.2019.100596

10. Y. Xu, Y. Zhang, D. Zhang, J. Ma, W. Yi, J. Zhang, and H. Shi, J. Energy Stor., 26: 100995 (2019); https://doi.org/10.1016/j.est.2019.100995

11. E. A. Burakova, T. P. Dyachkova, A. V. Rukhov, E. N. Tugolukov, E. V. Galunin, A. G. Tkachev, A. A. Basheer, and I. Ali, J. Mol. Liq., 253: 340 (2018); https://doi.org/10.1016/j.molliq.2018.01.062

12. G. Defu, L. Meiying, H. Hongye, C. Junyu, and D. Jibo, J. Molec. Liq., 271: 246 (2018); https://doi.10.1016/j.molliq.2018.08.079

13. K. Zare, H. Sadegh, R. Shahryari-ghoshekandi, B. Maazinejad, V. Ali, I. Tyagi, Sh. Agarwal, and V. K. Gupta, J. Molec. Liq., 212: 266 (2015); https://doi.org/10.1016/j.molliq.2015.09.027

14. T. Ahamad, Mu. Naushad, G. E. Eldesoky, S. I. Al-Saeedi, A. Nafady, N. S. Al-Kadhi, A. H. Al-Muhtaseb, A. A. Khan, and A. Khan, J. Molec. Liq., 282: 154 (2019); https://doi.org/10.1016/j.molliq.2019.02.128

15. T. Zhao, X. Li, Y. Wang, J. H. S. Lee, and H. Yan, Mater. Res. Bull., 102: 153 (2018); https://doi.org/10.1016/j.materresbull.2018.02.033

16. J. H. Lehman, M. Terrones, E. Mansfield, K. E. Hurst, and V. Meunier, Carbon, 49: 2581 (2011); https://doi.10.1016/j.carbon.2011.03.028

17. Q. Gao, F. Wu, J. Hu, W. Chen, X. Zhang, X. Guo, B. Wang, and X. Wang, Sci. Tot. Envir., 716: 137017 (2020); DOI: 10.1016/j.scitotenv.2020.137017

18. A. Mohammadi and P. Veisi, J. Envir. Chem. Engin., 6, No. 4: 4634 (2018); https://doi:10.1016/j.jece.2018.07.002

19. I. Kosogina, I. Astrelin, G. Krimets, and N. Vereshchuk, Chem. Chem. Technol., 8, No. 3: 365 (2014); https://doi.org/10.23939/chcht08.03.365

20. G. Diao, H. Li, H. Liang, I. Ivanenko, T. Dontsova, and I. Astrelin, NANO: Brief Reports and Reviews, 13, No. 4: 1850036 (2018); https://doi.10.1142/S1793292018500364 